\title{
STUNTING OCCURENCE HANDLING EFFECTIVENESS IN REDUCING STUNTING PREVALENCE IN BOJONEGORO
}

\author{
Evita Muslima Isnanda Putri 1), Nur Azizah 2) \\ 1)2) Akes Rajekwesi Bojonegoro \\ Corresponding e-mail : evita.muslimah@gmail.com, aziezahmaulana@gmail.com
}

\begin{abstract}
BACKGROUND : Indonesia is currently facing nutritional problems which seriously affect its human resource. One of the main issues is the high rate of short toddlers (stunting). According to Sustainable Development Goals (SDGs), all kinds of malnutrition, including stunting, must be overcome. This research aimed to reveal driving factors that affect stunting prevalence in Bojonegoro and programmes carried out to handle stunting in the region.

SUBJECT AND METHODE : This study uses phenomenology as its design and retrospective as its time approach. Meanwhile, the subjects observed are main informant and supporting informant related to stunting handling programme. The writers also functioned as the main instruments of the study by using triangulation, including in depth interviews and documentation, as the data collecting technique.

RESULTS: The study results show that stunting prevalence is affected by the decreasing rate of exclusive breastfeeding between 2016 and 2017. The Public Health Bureau of Bojonegoro has made some efforts to accelerate the prevalence reduction by prioritising nursery room provision in offices and stunting audit programme as included in PESTA GITA (Toddlers Nutritional Level Improvement) programme.

DISCUSSION: However, there are several obstacles in its implementation, and they are expected to be fixed soon by creating cross-sector collaboration. Furthermore, organised programmes are expected to be benchmarks and recommendations to be carried out consistently and continuously.
\end{abstract}

\section{Key words: stunting, handling, nutritional intervention}

\section{INTRODUCTION}

Nowadays, Indonesia is facing serious issues that affect its human source. One of the most common nutritional problems is stunting. Sustainable Development Goals (SDGs) aims to focus on stunting, wasting, and overweight in children younger than 5 years old (UNICEF, 2018). Stunting itself is caused by malnutrition and/or infections which often occur on children. This condition increases children mortality rate, intelligence, and motoric development, raises susceptibility to diseases, reduce productivity, detains economic growth, and inclines poverty rates and social inequality (Torlesse, Cronin, Sebayang, \& Nandy, 2016).

This condition increases children mortality rate, intelligence, and motoric development, raises susceptibility to diseases, reduce productivity, detains economic growth, and inclines poverty rates and social inequality. Stunting decreasing number in Bojonegoro is used as benchmark of the success in stunting handling in the area.

According to National Basic Health Research between 2007 and 2013, there is a concerning fact about this issue in Indonesia: the rate of stunting increased from $36.8 \%$ to $37.2 \%$ (Andriani, WD, \& Nurzalmariah, 2017). Furthermore, stunting prevalence in Indonesia in 2015 rise to 29\%, which then 
declined to $27.5 \%$ in 2016. Meanwhile, the level of stunting occurrences in Bojonegoro was at $7.46 \%$ in 2016 and slightly declined to $7.10 \%$ in 2017. Additionally, stunting prevalence in Balen Public Health Centre in 2016 was at 16.58\%. This rate decreased to $14.38 \%$ in 2017 (Nutrition Section of Public Health Bureau of Bojonegoro, 2017).

Up to now, there are several regions in Indonesia which show increasing rates of stunting prevalence. This study aimed to explain effective stunting handling efforts in order to reduce stunting prevalence in Bojonegoro.

\section{METHODS}

This research applied qualitative approach with phenomenology as its design. It is a retrospective study whose research subject consists of the head of stunting handling programme in Public Health Bureau of Bojonegoro and the head of nutrition programme of Balen Public Health Centre, Bojonegoro. Meanwhile, the research instruments of this study are a combination of in depth interviews and study of documentation.

\section{RESULTS AND DISCUSSION}

\section{Factors influencing stunting in Balen Public Health Centre as well as in Bojonegoro in general}

Identification of factors which affect stunting occurrences was carried out by studying documentation and in depth interview of research subject-henceforth shall be referred to as participants. Participant 1 in this research is nutritionist of Balen Public Health Centre who holds the position as the head of stunting handling programme in the centre. Meanwhile, Participant 2 in this research is the head of stunting handling programme of Public Health Bureau of Bojonegoro. The results of the study indicate that factor which affects stunting prevalence in Balen Public Health Centre and Bojonegoro in general is the declining access to exclusive breastfeeding between 2016 and 2017.

\section{Solutions to stunting applied by Balen Public Health Centre}

Participant interviews in Balen Public Health Centre reveal that the centre has applied several solutions to overcome stunting, namely socialisation by the public health centre cadres during Public Health Service or nutritional counselling in Balen Public Health Centre.

There was a new innovation applied to handle stunting occurrences in Balen Public Health Centre in 2019. The health centre cadres took training on measuring baby height accurately using standardised measuring instrument called length board.

Balen Public Health Centre also carried out visit and tracking programmes with a team consisting of doctors, nutritionist, midwives, and head of environmental sanitation/health programme. These activities include physical examination, interviews, and observations related to stunting causes. 
However, there are several problems in this programme. Length boards are not yet provided in every public health service thus body height measurement has not yet been able to be measured accurately. Furthermore, there is lack of supervision and monitoring by nutritionists in charge because there is only 1 (one) nutritionist in Balen Public Health Centre.

\section{Solutions to stunting applied by Public Health Bureau of Bojonegoro}

The percentage of stunting prevalence in Bojonegore increased between 2016, 2017, and 2018, with $7.1 \%, 7.46 \%$, and $8.7 \%$ respectively. Previously, it had decreased yet it went up through the three year period.

Based on participant interviews, there are several aspects which cause this increase in 2018, such as: 1) the implementations of nutritional post and supporting group for breastfeeding which have not been optimised in villages; 2) low levels of supplementary food provisions for pregnant women and for babies; 3) lack of hygiene of public sanitation; 4) lack of collaboration cross-sector in the society; and 5) lack of nutritionists in the public health centre.

In order to improve nutritional levels in Bojonegoro, the Public Health Bureau of the region implements a programme called 4 (four) Pillars of PESTA GITA (Perbaikan Status Gizi Balita), Toddlers Nutritional Level Improvement, namely: 1) Community Empowerment, 2) Nutrition Socialisation, 3) Nutritional Intervention, and 4) Cross-Sector Collaboration.

There was a growth in stunting prevalence level in 2018. Then, the bureau modified PESTA GITA programme by adding nursery room provision programme in offices and stunting programme audit on Nutritional Intervention.

Nursery room provision in offices programme have been socialised through a circular letter issued by Bojonegoro government No. 440/2196/412.202/2019, which instructed village officials, public service offices, municipally-owned enterprise (BUMD) offices, state-owned enterprises (BUMN) offices, and private-owned institutions/offices within Bojonegoro area to provide nursery room in their workplaces.

Stunting Audit Programme includes 7 (seven) evaluation items, namely: a) family identification data including parents and toddlers' identities; $b$ ) health and nutritional levels of mothers and toddlers; $c$ ) child care patterns (breastfeeding and supplementary foods); d) mothers' knowledge about nutrition; e) family and environmental hygiene; f) pregnancy and labour records; and g) mothers and toddlers' health. This programme is one of national prioritised activities in stunting reduction acceleration programme regulated by the Public Health Bureau of Bojonegoro in accordance to the circular letter issued by the head of the National Public Health Bureau No. 440/2680/412.202/2019 on Operational Instructions on Stunting Reduction Acceleration Programme implementation.

Exclusive breastfeeding is a specific intervention yet is extremely short. The research results show that between 20016 and 2017, the number of exclusive breastfeeding dropped. However, the rate of stunting prevalence within the same period also decreased. This indicates that exclusive breastfeeding is not directly related to stunting prevalence at the time. Nevertheless, it affected the prevalence in the next two years, thus, similar to what was stated in Health Profile of Bojonegoro, the prevalence rose in 2018. 
Stunting may occur since the foetus phase, and it is going to be physically apparent when the child is two years old (WHO, 2010). Nevertheless, the possibility rate may decline if the mother provides exclusive breast milk for the baby.

Furthermore, Balen Public Health Centre has applied efforts to overcome the increasing level of stunting prevalence by carrying out socialisation, counselling, and public health service cadre empowerment in measuring toddlers' height using standardised equipment. The cadres, consisting of Human Development Cadres, help villages in facilitating integrated intervention in stunting reduction programme. One of their tasks is to improve public awareness of the issue by measuring babies and toddlers' height as early detection of stunting. The measurement was done using anthropometry provided by the Public Health Centre. Body length of toddlers younger than 2 (two) years old was done in sleeping position using length measuring board. Meanwhile, body height of those older than 2 (two) years old was measured in standing position using microtoise (Indonesian Ministry of National Development Planning, 2018) $)^{5}$.

There are several obstacles found in stunting handling programme, such as lack of standardised measuring tools in public health services within Balen Public Health Centre work area, hence measurement inaccuracy. Village budget allocation is required to facilitate public health cadres with the needed equipment to help them measure toddlers' body height/length as early detection of stunting.

Other efforts carried out by Balen Public Health Centre in the stunting handling programme are visit and tracking by a team doctors, nutritionist, midwives, and head of environmental sanitation/health programme. This activity is a part of stunting audit programme socialised and implemented by the Public Health Bureau of Bojonegoro. In other words, Balen Public Health Centre gives great supports for the stunting reduction acceleration programme regulated by the Public Health Bureau of Bojonegoro.

The National Public Health Bureau's main task and authority in health sector is holding a prominent role in accelerating stunting prevention in cities/districts; the task is especially related to specific nutritional interventions (National Team for the Acceleration of Poverty Reduction, 2018). Therefore, in the specific nutritional intervention programme included in PESTA GITA (Toddlers Nutritional Level Improvement), the Public Health Bureau of Bojonegoro adds and prioritises nursery room provision in offices as a support for exclusive breastfeeding programme which in turns gives impacts to stunting prevalence growth in Bojonegoro.

Additionally, Public Health Bureau of Bojonegoro has started socialising the stunting audit programme as an effort to reduce the level of stunting occurrences in all of the Public Health Centres in Bojonegoro. This is in accordance to their role in improving local nutrition surveillance system equipped with accurate, quick, and adequate case detection and reference systems (National Team for the Acceleration of Poverty Reduction, 2018).

\section{CONCLUSION}

Exclusive breastfeeding has no direct relation to stunting occurrences prevalence yet affects future stunting prevalence. Specific and sensitive intervention programme in Bojonegoro is carried out by 
prioritising nursery room provision in offices and stunting audit programme as efforts to accelerate stunting prevalence reduction.

\section{REFERENCES}

UNICEF. (2018, Mei). UNICEF. Retrieved from UNICEF: https://data.unicef.org/wpcontent/uploads/2018/05/SDG-briefing-note-3_nutritional-status.pdf

Torlesse, H., Cronin, A. A., Sebayang, S. K., \& Nandy, R. (2016). Determinants of stunting in Indonesian children: evidence from a cross-sectional survey indicate a prominent role for the water, sanitation and hygiene sector in stunting reduction. BMC Public Health, 1-11.

National Team for the Acceleration of Poverty Reduction. (2017). 100 KABUPATEN/KOTA PRIORITAS UNTUK INTERVENSI ANAK KERDIL (STUNTING). Jakarta: National Team for the Acceleration of Poverty Reduction.

Nutrition Department of Public Health Bureau of Bojonegoro. 2017. Health Profile of Bojonegoro.

Indonesian Ministry of National Development Planning (2018). PEDOMAN PELAKSANAAN INTERVENSI PENURUNAN STUNTINGTERINTEGRASI DI KABUPATEN/ KOTA. Jakarta: Indonesian Ministry of National Development Planning.

National Team for the Acceleration of Poverty Reduction. (2018). Panduan Konvergensi Program/ Kegiatan Percepatan pencegahan Stunting Buku Pegangan Resmi Organisasi Perangkat Desa (ODP). Jakarta: National Team for the Acceleration of Poverty Reduction. 